\title{
Participatory Mapping of Local Disaster Risk Reduction Knowledge: An Example from Switzerland
}

\author{
Christian Reichel • Urte Undine Frömming
}

Published online: 29 March 2014

(c) The Author(s) 2014. This article is published with open access at Springerlink.com

\begin{abstract}
This article is based on comparative anthropological fieldwork conducted in the Alpine region of Switzerland on sustainable environmental knowledge about natural hazards related to climate change. It examines ways to complement the normative and technological practices of risk management by using local knowledge to improve the resilience of affected communities against climate-related risks. The study shows how agricultural practices and knowledge may contribute to sustainable behavior towards nature and the environment. It explores how local environmental knowledge, perceptions, and handling strategies of climate-related risks may be integrated within a renewed concept of environmental sustainability. Participatory GIS mapping (PGIS) is the primary research method used. Based on applied visual anthropological methods, PGIS is a cartographical approach that integrates local perceptions and strategies of action drawn from interviews and participant observation. This approach enables improved communication of local knowledge and contributes to interdisciplinary cooperation between different academic fields, such as social anthropology, geography, and civil-engineering in the context of technological risk management. The approach encourages the active participation of local people in the process of sustainable risk management through the integration of cultural meanings and local knowledge about the sustainable management of sensitive natural environments.
\end{abstract}

Keywords Alps · Environmental anthropology · Natural hazards · Participatory mapping · Switzerland

C. Reichel $(\varangle)$ · U. U. Frömming

Institute of Social and Cultural Anthropology,

Freie Universität Berlin, 14195 Berlin, Germany

e-mail: christian.reichel@fu-berlin.de

\section{Introduction}

In this article we discuss the question whether traditional ${ }^{1}$ patterns of interpretation and practices provide useful alternatives or at least additional strategies to "negotiate disaster" (Luig 2012), and to what extent these traditional patterns respond to the challenges posed by climate change. Closely linked to this discussion, our research shows that knowledge about how to protect rare resources and endangered environments was and still is in many societies based on deeply rooted cultural ideas that enable societies to implement rules to protect the environment and to cope with natural hazards (Reichel et al. 2009).

The key research questions that were posed for this study in the Safien valley in Switzerland are:

(1) What kind of local ${ }^{3}$ environmental knowledge exists to protect against and to cope with natural hazards in times of climate change?

\footnotetext{
1 The term "traditional" is not used here to denote the strict conservatism that keeps internal social systems stable and encourages resistance to innovations from outside. Rather, the transition between "traditional" and "modern" is understood to be fluid, where elements of old knowledge are replaced by new insights (Schultze 1998).

2 A disaster is a damaging event that undoes or at least massively disrupts the victims' "readability of the world." Readability refers to those forms of cultural interpretations of the world that allow people to orient themselves, make decisions, and create contexts. The resulting interpretations enable people to understand and respond appropriately to each situation. In this sense, disasters are events that do not fall into the traditional framework of interpretation, but rather demand a significant change or even a new foundation (Blumberg 1986).

3 This knowledge can be described as local because it is acquired with regard to the intentions, problems, and events that emerge or take place in a specific natural, social, and cultural context. However, as we will describe later, local knowledge is also defined by global interconnections.
} 
(2) How is this knowledge embedded in local cultural concepts, how does it change over time, and how is it distributed?

(3) How is the global discourse about climate change perceived and interpreted locally, and in which way do these perceptions relate to the ability of societies to adapt to unpredictable environmental changes?

(4) What are the possible applications of local environmental knowledge that lead to increased vulnerability or resilience in the pursuit of civil protection.

Since the Intergovernmental Panel on Climate Change (IPCC) issued its fourth assessment report in 2007 (IPCC 2007), there has been hardly any doubt among climatologists about the existence of anthropogenic climate change. Although the global warming that is caused by climate change affects the entire world, the effects, consequences, and causes of climate change are not the same globally. They manifest themselves physically in very different forms based on interactions with context-specific environmental, economic, and social frameworks (Dietz 2006).

The Alps are a particularly climate-sensitive region and, according to forecasts, climate change and its effects will be noticeable in Alpine regions sooner and more intensely than on the global average (BAFU 2013). This is substantiated by regional variations in the increase of global temperatures. While the average global temperature has increased by $0.7^{\circ} \mathrm{C}\left( \pm 0.2^{\circ} \mathrm{C}\right)$ during the past 100 years, temperatures in the Alps have increased by $1.6^{\circ} \mathrm{C}$. As a result, the frequency and strength of climate change-related natural hazards are likely to increase at a particularly high rate (OcCC 2003, 2007; MeteoSwiss 2013). However, the heterogeneity of the natural regions in the Alps makes it difficult to provide a detailed forecast of the impact on environmental changes caused by an increase in temperature.

Modeling indicates that there will be an increase in the magnitude and frequency of heavy precipitation (BAFU 2013). This results in an intensification of the hydrological cycle. These increases of precipitation will not only make more mass movements such as landslides likely, but they will also increase flood risks in volatile river areas within the often narrow Alpine valleys. Between 1999 and 2005, there were five periods of extreme precipitation ${ }^{4}$ in the

\footnotetext{
${ }^{4}$ Extreme precipitation in the form of heavy rain or snowfall is mostly triggered through convective (cumulonimbus) clouds. It can lead to rapidly rising water levels and flooding, which is often accompanied by soil erosion. The German Weather Service (DWD) has set the warning criteria for heavy rainfall to a precipitation intensity of $25 \mathrm{~mm} / \mathrm{h}$ and $35 \mathrm{~mm} / 6 \mathrm{~h}$ (DWD 2014). Whether extreme precipitation actually causes a flood event depends on a range of factors, most notably the characteristics of the soil and the geological subsurface. The long-lasting snowfall in the Alpine avalanche winter of 1999 was due to 3 consecutive days of stationary front weather. In
}

Alps that increased the probability of mass movements and avalanches (avalanches in winter of 1999, floods of May 1999, floods of October 2000, the October 2000 landslide in Gondo, and the floods of August 2002 and August 2005) (ANiK 2013).

The temperature increase also means that small glaciers are expected to disappear, while larger glaciers will suffer a volume decrease of up to $70 \%$ by 2050 . Although the period between 1985 and 2000 experienced particularly hot summers, the Swiss glaciers have lost $20 \%$ of their mass within only the last 15 years. In addition to a decrease of water resources, the decline of ice is leading to a loss of stability of adjacent slopes (Rebetez 2006). Furthermore, approximately $5 \%$ of Switzerland's surface area is formed by permafrost, which is very sensitive to temperature increases. Most of this surface area consists of rockwalls at an altitude of $2,500 \mathrm{~m}$, which are stabilized by the permafrost. If the permafrost continues to thaw, it is expected that there will be an increase in shallow landslides, and large rockslides with enormously destructive amounts of impact energy (Rebetez 2006; OcCC 2007).

Triggered by the climate change discourse, professionals in risk management, such as scientific advisors and political actors, increasingly realize that these new uncertainties related to environmental changes have to be included into their calculations, instead of maintaining current action plan routines. As Dr. Ruedi Haller, the head of the Research and Geospatial Information Section at the only Swiss National Park, indicated with regard to the significant changes in weather patterns in recent years, which he related to climate change:

The processes of change can be clearly detected by our monitoring stations. We note that extreme events have increased and the costs for maintaining the public infrastructure are much higher than before. Especially heavy precipitation has increased extremely over recent years. Also, the situation this year... extremely heavy snow, extremely late in the year, extremely low temperatures, and then extreme warmth all of a sudden. These extreme shifts did not exist 10-15 years ago. Through the temperature increase, extreme events and weather situations have become unpredictable, which in turn has an influence on the elements of wind, temperature, and precipitation (Interview with Dr. Ruedi Haller, Swiss National

Footnote 4 continued

less than 5 weeks, more than $5 \mathrm{~m}$ of snowfall were recorded in large parts of the Alps. This period of heavy snowfall was accompanied by stormy winds and an extensive drifting of fresh snow, especially to steep slopes near ridges, which in turn increased the probability of large avalanches (BAFU 1999). 
Park in Zernez, February 2012. Quote translated from German to English).

In addition to drawing the attention of experts, this environmental change also leads to an enormous amount of insecurity on a societal level about how to cope with natural hazards. Thus, previously established environmental knowledge now seems to lose some or all of its validity. As Dr. Felix Keller, a glaciologist, pointed out:

What most people do not realize in relation to climate change is that we also lose our memory. Our experiential knowledge is suddenly no longer valid. Nature changes so quickly that in certain places new hazards arise that previously did not exist. Other places that were very dangerous in the past are suddenly not so dangerous anymore (Interview with Dr. Felix Keller, Samedan, June 2011. Quote translated from German to English).

In the Swiss Alps, risk management professionals regard the implementation of new climate change adaptation strategies, such as the Swiss integrated risk management approach National Platform for Natural Hazards (PLANAT) as the right step forward. PLANAT is a comprehensive and holistic approach, which considers a broad range of preparedness, response, and recovery strategies on a societal level for natural hazard risk reduction (PLANAT 2013). In addition to focusing on technical possibilities as an instrument to protect against natural hazards in times of climate change, for example by improving the infrastructure of avalanche fences, there is an increasing consensus that the involvement of local actors, with their own social and cultural concepts about natural hazards, into professional management processes is necessary (Kruse and Wesely 2013). This would allow for an improvement of existing professional management strategies based on the insights of local actors' knowledge, while also contribute to an increased level of acceptance of relevant policies among the local population.

On a theoretical level, local environmental knowledge is increasingly being recognized as an important component in risk management. However, through our research it became apparent that professional actors of risk management do not yet fully implement the potential of local frames of reference and strategies of action into their risk management plans, even though this kind of knowledge contains various prevention, coping, and adaptation strategies that deal with expected future uncertainties (Frömming 2006; Crate 2009; Voss 2010; Frömming and Reichel 2011; Reichel et al. 2012). The participatory mapping methods presented below provides a tool for integrating local mitigation and adaptation strategies to better cope with global phenomena.

\section{Research Region: Safien Valley, Switzerland}

The chosen research area is the Safien valley, a municipality of the Swiss Canton (administrative unit) Graubünden. The approximately $25 \mathrm{~km}$ long trough valley covers an area of $151.43 \mathrm{~km}^{2}$ (Municipal Government Safien 2014), and is enclosed to the south, east, and west by about 2,000-3,000 $\mathrm{m}$ high mountain ridges and in the north by the Rhine Gorge. It is populated at an altitude of between 800 and $2,500 \mathrm{~m}$. The entrance to the valley is steep and narrow and the main natural hazard occurrences include avalanches, mudslides, and rockfalls.

The population of the entire valley consists of 921 people (FSO 2014). The four villages of Versam, Valendas, Tenna, and Safien are characterized by scattered settlements, with mountain farms that stand far apart from each other. The valley's inhabitants are almost exclusively farmers who keep livestock on highly subsidized family farms. Overall, $45.6 \%$ of the valley's surface is used as agricultural land, but the meadows and pastures are consistently broken up by deep ravines and wooded areas (Steinmann et al. 2008; FSO 2014). Until the late 1950s, when a new road was built, the valley remained largely isolated for long periods of up to several months during times of heavy rain or significant snowfall. Even today, the well-developed road that leads out of the valley can be blocked for several days under heavy snow conditions because of avalanche danger.

\section{Methodology}

This study is based on a combination of anthropological research methods, including participatory observation and structured, as well as semistructured interviews and geographical methods of visualization and mapping. All data generation was conducted in the context of long-term fieldwork. The combination of diverse research methods helped to identify and disclose interpretative frameworks and related handling strategies of natural disasters and climate change.

\subsection{Participatory Observation}

With the aim to obtain informal access into social networks and to comprehend common practices and interpretation patterns among local groups, the lead author conducted ethnographic research based on participatory observation and audiovisual interview techniques. A total of 6 months was spent on various mountain farms in the Safien valley between 2011 and 2012. In order to explore local knowledge about environmental changes, the researcher's integration into the social context in which this knowledge is created, evolves, and 
is used was essential. This integration was achieved by the long-term presence of the researcher in the valley, and his continuous interaction with a large number of informants. ${ }^{5}$

\subsection{Participatory Mapping}

Participatory mapping is a powerful tool for providing a visual representation of how local communities perceive their physical environment and the significant features within it, based on culturally distinct ideas, concepts, and norms (IFAD 2009b). Techniques such as mind mapping, scale mapping, and multimedia mapping allow for the visualization of these culturally distinct perceptions, and they help make explicit implicit frames of references and related handling strategies. The method is participatory in the sense that it goes beyond simple one-way interaction between researcher and informants. The informants were involved in the entire research design and implementation process. The local people discussed and decided themselves which issues were important, and how these should be visualized on a map. From the authors' experience, the technique of participatory mapping is a very helpful tool for acquiring local sustainable environmental knowledge. The importance of participatory mapping rests on four major elements:

(1) It provides a communication platform between local groups and political decision makers to communicate the spatial knowledge of the local people;

(2) It facilitates interdisciplinary research; complex information can be presented to different scientific communities in a format that is easy to understand and manage;

(3) Participatory mapping allows local communities to record local knowledge; in addition to this being valuable for historical and preservation aspects, it enables people to share ideas and visions, strengthening their capacity to address environmental changes;

(4) Participatory mapping encourages the active participation of communities in the processes of sustainable risk management by integrating cultural meanings and local knowledge about sustainable environmental

\footnotetext{
5 The research followed the idea that the cultural diversity of divergent patterns of interpretation and adaptation strategies could only be represented on the basis of several regional case studies. Although this will be not part of this article, additionally to the Safien valley, the first author of the present article conducted a 7-months field research based on participant observation in three Alpine research areas between 2011 and 2013 (Pontresina in Switzerland, Galtür in Austria, and Bad Hindelang in Germany). This research was part of the interdisciplinary research project "Alpine Hazards in Times of Climate Change. Patterns of Interpretation and Strategies of Action from the 18th to the 21 st Century" (ANIK-Alpine Naturgefahren im Klimawandel).
}

management of sensitive natural environments into government strategies (IFAD 2009a).

Another aim of this research is to compare already existing hazard maps with the local perceptions and cultural meanings of sensitive environments. In order to be able to visualize recommendations for protection zones and danger zones, according to Sturm's concept of space, the above elements are analyzed through a multidimensional analytical approach, which includes the involvement of natural space, institutions, society, economics, and culture (Sturm 2000).

However, as described by Heesen and colleagues in this Special Issue, maps define spaces and draw boundaries and are not drawn within a social power vacuum (Heesen et al. 2014). Since maps are often mistaken as meaningful representations of reality, those who create them carry a great responsibility. As Chambers (2006, p. 1) emphasized, "The medium and means of mapping, whether ground, paper or GIS, and the mode of facilitation influence who takes part, the nature of outcomes and power relationships. Much depends on the behavior and attitudes of facilitators and who controls the process." Therefore, it is important to be very sensitive when deciding which mapping technique is appropriate and when to use local symbols (Chambers 2006). The following mapping techniques were applied in the field to capture the local population's dominant and subjective perceptions of Alpine space and place.

\subsubsection{Sketch Mapping}

Sketch maps are freehand drawings on a piece of paper using different colored pencils (Fig. 1). Although simple, the technique is very useful for visualizing a bird's-eye view of a particular environment from the perspective of personal perceptions of space. For example, in localities where Christianity plays a major role in society, the participants' drawings often started with a symbol of the church directly in the middle of the paper. One conclusion could be that for that person the church represents the central point of social interactions. The major strengths of this method are that the creation process is totally intuitive. For example, the person chooses him- or herself which symbols they prefer to use. The map is easily facilitated and not dependent on technology. One of its major weaknesses, however, is that the output is not georeferenced and cannot be directly transferred into a scale map or a geographical information system (GIS). The associated lack of geographical accuracy makes it more difficult to communicate results to political decision makers (IFAD 2009a; Wood 2012).

\subsubsection{Scale Mapping}

Scale maps allow not only the visualization of qualitative data but also georeferencing. To create a scale map, a transparent film is attached to a high-resolution aerial image or a topographic map. When creating the map, it is possible to 


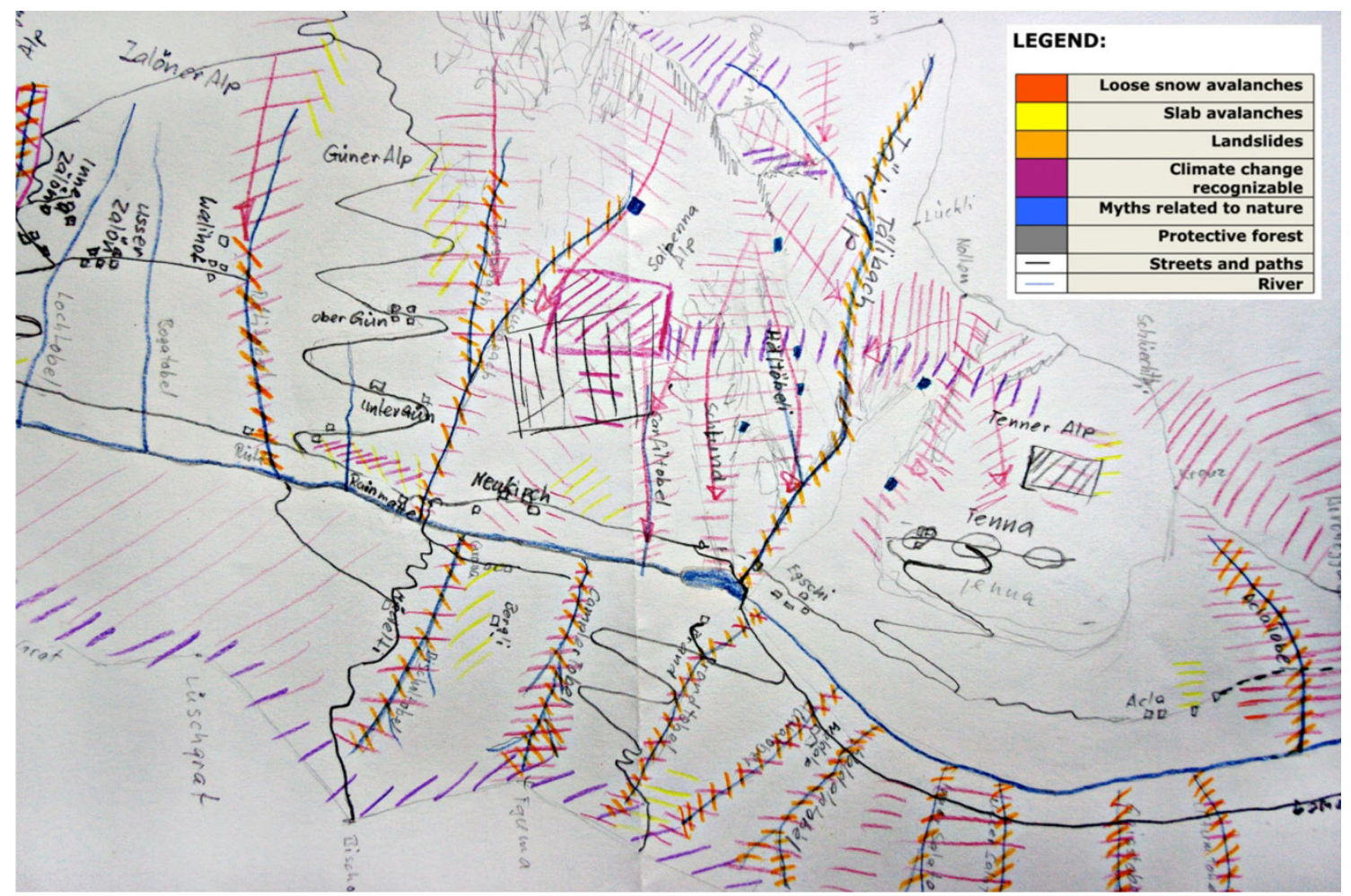

Fig. 1 Example of a sketch map that shows how natural hazards are perceived by a study participant in Safien, Switzerland. When producing the map, the only guideline was to draw the natural hazards that are relevant for the informant. Photograph by C. Reichel, Tenna, July 2012

draw directly onto the film (Fig. 2). Putting several slides on top of each other, overlaps or differences between individuals or groups can be easily identified. Since all of the data are based on a georeferenced map, they can also be transferred relatively easily to a GIS. Not only are these maps low cost, easily facilitated, and not dependent on technology, they are also very effective for determining quantitative and qualitative information, for example, when the size of a subjectively perceived risk-prone area is mapped out, or the distance between two geographical points is determined. Even though this does not apply to Switzerland, one of the major weaknesses of this method is that it can be difficult to access detailed and georeferenced scale maps, satellite images or aerial pictures, especially in rural areas of low- and middle-income countries or when the military is holding back georeferenced maps in a smaller scale for security reasons (IFAD 2009b).

\subsubsection{Multimedia Mapping}

The use of multimedia maps - the combination of video and audio material with a georeferenced map-offers a particularly valuable possibility for visualizing the hidden structures of environmental knowledge and enables the researcher to analyze the deep connection of this knowledge to the people's perception of the environment (Ingold 2000). The multimedia

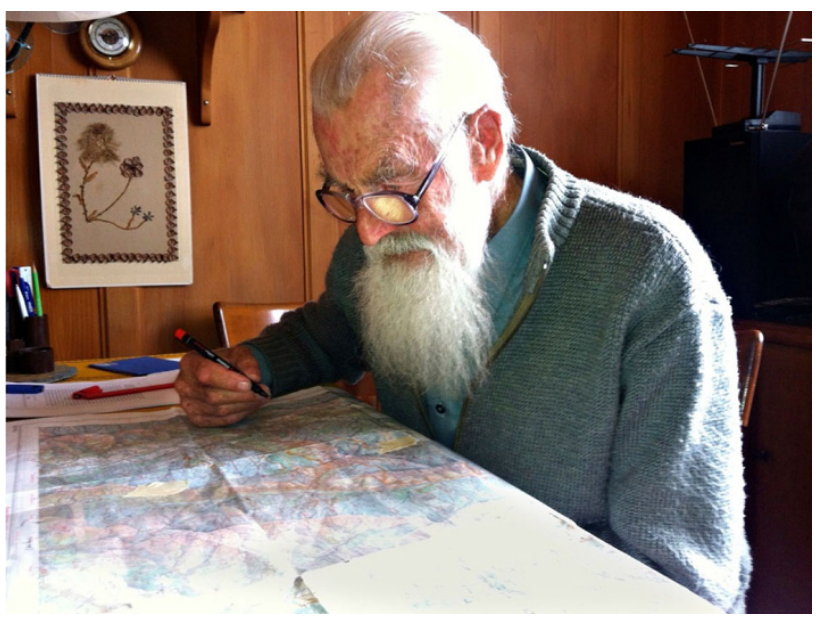

Fig. 2 Scale mapping of natural hazards with a former district forester and farmer family in Safien, Switzerland. Photography by C. Reichel, Safien Platz, January 2012

map presented in Sect. 4.1 directly links research results, images, and audio and video sources with specific locations in the Safien valley research area. This information is made available with a simple mouse click. Users are offered a regional overview of the research area as well as specific research content, which is made available for this very purpose. The entire process of creating this multimedia map, from 


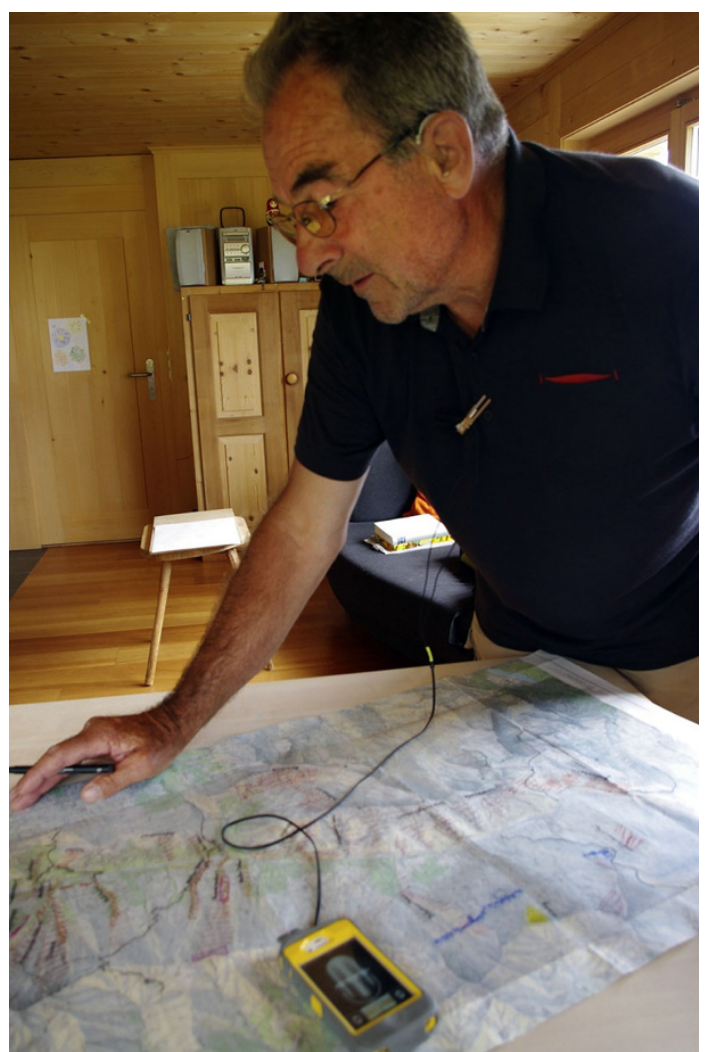

Fig. 3 Recording an audio material for a multimedia map with a former carpenter. Photograph by C. Reichel, Tenna, July 2012

data collection to the creation of the map, was guided by reciprocity. This means that at each step, several feedback sessions were held to define and discuss necessary corrections of the map. The use of a video camera and its subsequent image analysis provides a way to better understand the lives of the locals in retrospect and to make implicit patterns of interpretation explicit. Our aim was to go "beyond observation cinema" (McDougall 1995) by encouraging the local groups "to speak for themselves" (Banks 2001). This means that an interview (Fig. 3) is initially recorded and edited on an audiotape or video. With the help of a GIS program, the interview material is then georeferenced and linked with a map. What results is a multimedia map that allows local knowledge for certain regions to be retrieved interactively. For example, if an interview about the perception of the environment in the valley is filmed, this film is marked on the map and can be viewed directly. The major weakness of this method is that the process of photo and video production and editing is very time-consuming and requires detailed technical skills. Moreover, deciding whether to use or not use a film and/ or photo-camera as a tool for qualitative data collection is a very sensitive process, especially in intimate situations. When introducing the method, only after spending several weeks or months in the field is it possible to access people's daily lives without bothering them by the presence of the camera.

\section{Results}

Based on a holistic approach, the anthropological data not only showed local perceptions of climate change, but also what different coping strategies in agriculture and forestry were used in order to face related natural hazards. These local frames of reference and coping strategies both have an impact on how vulnerable or resilient local communities are in times of climate change. This in turn is important for adaptive risk management dealing with new uncertainties in an ecological and societal change.

\subsection{Local Environmental Knowledge to Protect Against and Cope with Natural Hazards in Times of Climate Change}

The research in the Safien valley revealed that traditional environmental knowledge and traditional coping strategies to adapt to a harsh natural environment still play a major role in the informants' epistemology. This finding stands in stark contrast to findings from earlier research in those localities of Switzerland that are characterized by large-scale alpine tourism, such as St. Moritz or Grindelwald. From 2011 to 2012, a total of 42 key informants were identified from various stakeholder groups through snowball sampling and interviewed using structured and semistructured interviews. During the participatory research, 14 key informants were accompanied for 6 months in their daily lives with the camera. We were then able to create a multimedia map and draw conclusions about the subjective perception of space.

\section{Multimedia Map Safiental}

This multimedia map brings together a plurality of different knowledge sources about coping strategies against natural hazards and the perception of climate change in the Safien valley. Since local environmental knowledge is neither static nor does it present a cohesive entity, but is rather evolving adaptively over time, we wanted to use a mapping format that is dynamic and interactive. Such a format can be contrasted with regular maps, which are often criticized for immobilizing peoples, places, and cultures (Massey 2000). The multimedia map format that we used allows end users of the map to choose between various map features to access multimedia information such as digital video, digital photos, and written text, which were georeferenced before being integrated into the map. The final map thereby helps users to compare, analyze, and present qualitative and quantitative spatial information. In addition, it creates a platform that visualizes local spatial knowledge and makes it directly comparable with official hazard maps in risk management.

Link: Multimedia Map Safiental (in German) 
Especially elderly alpine farmers from families who have lived in the valley for centuries, and who used to live and work under more challenging conditions than today, continue to remember traditional environmental knowledge and strategies for preventing and coping with natural hazards. This continuity can be explained by pointing to the following facts: the valley largely lacks technical defense structures against natural hazards, which means that the level of individual adaptation pressure is elevated. Most families have lived in the valley for many generations, and local conditions and former hazards are orally transmitted. Although farmers in the relatively remote Safien valley now have improved access to domestic and international markets for agricultural inputs, they largely remain dependent on the economic outputs produced exclusively on the basis of resources available in small geographical areas within the valley. For example, even though the farmers today are able to buy additional fodder to supplement the production on their land, farm sizes tend to be too small to make such investments profitable. As a result, most farmers continue to rely exclusively on their own production. Destructive use of the cultural landscape would be an existential threat to their material basis of life. Accordingly, the natural resources are generally used in ways that ensure the productivity of the cultural landscape for future generations (Bätzing 2005). In this regard, a farmer from Safien Platz said:

I learned a lot from my parents and grandparents. Things like when you cut the best wood in the winter, or what signs indicate a weather change. Since the people here import almost no hay for winter fodder and every farm has only a very small area to manage, they are forced to use the natural resources in a balanced way. So on the one hand, we can survive economically, and on the other hand, nature continues to give us and future generations what we need to live (Interview with a farmer in Safen Platz, January 2012. Quote translated from German to English).

Based on the data from the Safien valley, the following categories of traditional environmental knowledge were identified: agricultural and forestry use, weather patterns, and natural hazards. These strategies for local resource use necessitate very detailed knowledge about environmental conditions, including awareness about linkages between certain weather conditions during particular times in the year in certain localities and the occurrence of specific natural hazards, such as avalanches or mudslides. The fact that potentially dangerous areas generally carry a name related to a particular hazard event that happened there in the past demonstrates the important role played by an iconic cultural memory (Assmann 2011) in the context of disaster mitigation strategies. A further example of the differentiated environmental knowledge of the valley's small-scale, topographically structured landscape is that particular, often small localities (from mountain peaks to individual plots) have their own local names (flurnamen). These names provide a meaningful orientation within the cultural landscape.

\subsubsection{Sustainable Strategies in Agriculture and Forestry Use}

To protect the sensitive mountain environment, the local population practices specific sustainable strategies in agriculture and forestry use. In the Safien valley, the following traditional ways of utilization can be distinguished.

(1) Meadows: a species-rich meadow is a cultural product. Because it stores less water than the forest and water drains away evenly and creates no trenches, careful soil drainage is of great importance. In addition, the cutting time and the cutting frequency are important for achieving high biodiversity and higher nutrient levels of the fodder output (Bätzing 2005). For example, the traditional haying techniques, as shown on Fig. 4, allow scything by hand and can contribute to a sustainable and gentle fostering of the hillsides, in contrast to the use of a (combined) harvester machine.

(2) Forest: In the traditional use of forests on steep slopes larger forest patches are never struck at once. Only individual trees are taken at a time, creating a stepshaped structure of the forest that can retain its protective effect.

(3) The pastures: To ensure that pastures are able to regenerate and that a dense, species-rich vegetation cover is obtained, farmers need to take care not to over- or underuse their pastures by making sure that the appropriate number of animals is allowed to graze at any time (Bätzing 2005).

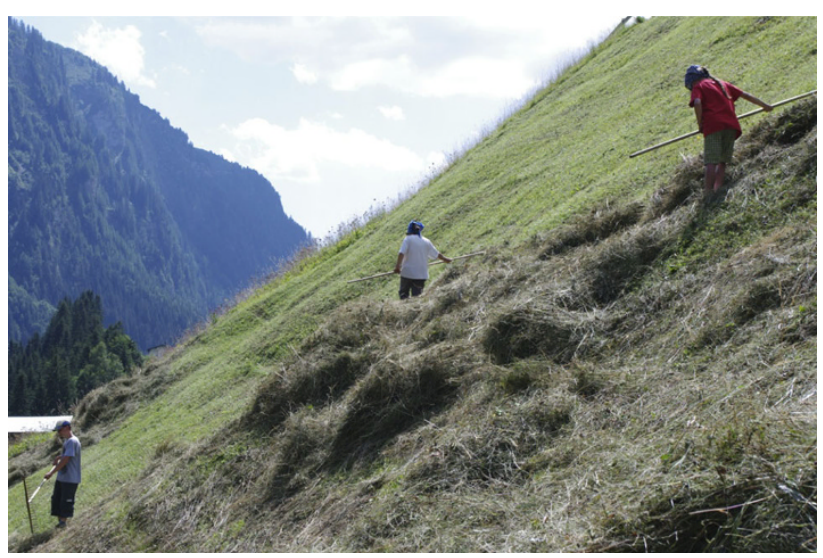

Fig. 4 Traditional haying techniques of scything by hand. Photograph by C. Reichel, Safien Platz, January 2012 
By applying these techniques, small-scale cultivated landscapes are maintained, which secures important ecological niches for a range of local plants and animals. For example, older farmers repeatedly claimed in their interviews that the biodiversity of mountain flowers, before the mechanization of agriculture, was much higher than today. The issue of biodiversity and agriculture was frequently brought up in interviews. One politically and emotionally charged question is how high the subsidy payments for extensive, ecologically sustainable agriculture should be. There is tension between farmers who prefer more extensive agricultural methods and those who do not; for example, some farmers prefer that certain steps in the working process, like scything, continue to be done by hand, while others prefer the use of machinery and intense fertilization.

\subsubsection{Myths as Cultural Memory of Natural Hazards}

Religion in environmental and climate change plays an important role. As Gerten and Bergmann stated, "religion is a highly promising analytic lens and an exemplary cultural microcosm for studying the manifold human modes of perception, action and thought (worldviews, moral systems, practices, aesthetic, ethics, lifestyles, hopes and fears) in relation to global change" (Gerten and Bergmann 2012 , p. 4) For the remembrance of special natural occurrences and natural hazards, religion and mythology play a significant role. One example of a transmitted myth on trespassing taboo knowledge is based on a story of the devil's attempt to destroy the church of Thalkirch, a small hamlet at the end of the Safien valley:

According to the story, when the church was built in 1441 , it angered the devil, who attempted to destroy it. He first dragged heavy stones over the so-called "Günner Hoora," a mountain pass close to the area where the church was built, and then threw these stones on the church from a distance. But in his anger and greed he did not realize that he took too many stones. His bag burst, and all the stones fell down the mountain slope while the church was safe. Unsurprisingly, at this very place a huge rockfall had occurred, but the time of its occurrence is unclear. The myth was one-way to commemorate the unique rockfall event and to verify the strength of the Christian faith against hazards. Interestingly, the "trespassing taboo" is nowadays still alive in the form of a wilderness-protected area with related restrictions (Interview with a carpenter from Tenna, January 2012. Quote translated from German to English).

Myths like these served a social, moral, and cathartic function (Frömming 2006) and were based on the idea that avalanches, landslides, and rockfalls were a punishment resulting from God's wrath. According to several key informants, in addition to this Christian interpretation, it was believed that the Safien valley was inhabited by mountain and forest spirits. These ideas were based on a cultural understanding of nature, rather than a naturalistic one, with nature being "objectively given" (Luig 2012). This means nature was not perceived as an object like in Western conceptual systems, but rather as a central point of orientation in society, in constituting its values, norms, and beliefs, as well as its identity (Frömming 2006).

In this sense, natural hazards are not only considered a source of danger, as in the scientific perspective, but also a warning or punishment from the mountain and forest spirits, as a result of nature's cultural construction. Especially in areas with Alpine forest, these interpretations had two important side effects: humans avoided areas endangered by natural hazards, and those areas were unaffected by anthropogenic use, effectively protecting them against natural hazards such as avalanches. Although this understanding of nature was replaced by a scientific and technological paradigm that emerged during the early Enlightenment in the second half of the seventeenth century (ANiK 2013), the myth of the Devil and the Rockfall in Thalkirch continues to be passed on to the next generation. The myth was even staged as a theater play at the elementary school of Safien during the time of the research.

The data from the Safien valley show that a wide range of local environmental knowledge exists in the fieldwork area. Much of this knowledge is directly relevant to the local population's ability to protect against and cope with natural hazards, the occurrence and intensity of which are likely to increase in times of climate change. However, an important finding of our research is that these bodies of local environmental knowledge are rarely taken into account by professionals in disaster control, and they generally do not inform avalanche records. Almost all key informants complained that their often highly differentiated knowledge about avalanches or mudflows was rarely considered in the creation of risk and hazard plans:

It's a shame that even though many local families gathered knowledge about the environment over centuries, their knowledge is not included when a hazard zone map is created. Since nobody asks about it, it is more and more forgotten. I personally know the mountains in this area very well. I worked as a shepherd since I was 15 years old. Every day I was out there. Later when I worked as a carpenter, I also became the leader of the avalanche rescue group from Safien. Even though I know exactly in which time of 
the year what kind of avalanche in which place could be dangerous, nobody from the officials who are working in the field of risk management has been interested in my knowledge. There are information evenings sometimes, when somebody official is coming from the Canton (administrative unit) and explains to us the situation and how we should live. Most of the people here think that's funny. But actually, from my point of view, it's sad (Interview with a carpenter from Tenna, February 2012. Quote translated from German to English).

One reason for this could be that too many institutional barriers ${ }^{6}$ exist to allow for the integration of practical local knowledge in meaningful ways. These include institutional barriers from below, such as the relatively weak capacity of local communities to identify, voice, and defend their interest in communicating their local knowledge at district and national levels. As a result, certain bodies of knowledge remain implicit and naturalized at the local level. For example, unwritten cultural rules about how to use natural resources in a sustainable way are not explicitly formulated, because they are seemingly obvious to the local population. Closely related are institutional barriers from above, which include the lack of institutional structures that allow for a systematic dialogue with carriers of local knowledge in the field of risk management.

Professional actors in hazard management frequently raised the argument that local environmental knowledge is too "subjective" for complementing existing "objective" scientific knowledge used by hazard and risk management plans. But from our point of view, instead of dichotomizing local knowledge and scientific knowledge, we should look for their affinities. "Objective" scientific knowledge and its underlying values are much less neutral than often claimed, ignoring certain values and issues and favoring others. As Foucault (1971) points out, "Therefore the criteria of what constitutes knowledge, what is to be excluded and who is designated as qualified to know involves acts of power"(Foucault in Scoones and Thompson 1994, p. 24).

\subsection{Change and Distribution of Embedded Local Environmental Knowledge}

It is important to emphasize that the concept of "local knowledge" should not be understood as a clearly defined epistemological space. It represents a field of study in which the importance of the contextuality of knowledgeor how it is embedded in local cultural concepts-is a defining factor. Generalizable aspects of local knowledge include the fact that any body of local knowledge is in a

\footnotetext{
6 These institutional barriers are noteworthy given that Switzerland has a well functioning direct democracy.
}

state of constant change, that it tends to be unevenly distributed among members of the community, and that it is integrated into a particular natural, social, and cultural context. Accordingly, any creative adaptation to a changing environment may also lead to destructive resource use strategies. For example, farmers cleared huge forests in the Safien valley during the fourteenth century to create space for pastures. At the time, local environmental knowledge was a driver of land degradation, which amplified hazard exposure. The local knowledge that encourages the maintenance of certain forests as a protection against avalanches and landslides by stabilizing the slopes only became commonplace over time, due to the repeated threat of landslides and avalanches to individual farms.

It is sometimes assumed that "local traditional knowledge" is dichotomous to universal scientific knowledge, but this assumption fails to recognize how different bodies of knowledge interlink, including bodies of local and scientific knowledge. Local knowledge is less defined by a rigid and locally confined structure, but is characterized by a mixture of local and translocal elements of knowledge (Agrawal 1995; Robertson 1995; Eichborn 2001; Frömming 2006). Through the process of "glocalization" (Robertson 1995), elements of global knowledge are constantly incorporated into local knowledge. If, for example, the environment (that is, the biological living environment as defined by nature or the social environment) changes due to increasing connections to national and international markets-enabling new economic perspectives for some groups-the bodies of local knowledge also change. This happens in an arena of social and cultural tensions, between the empowerment of other, nonlocal forms of knowledge and the creative adaptation or extension of local bodies of knowledge (Appadurai 1986; Tsing 2005; Reichel et al. 2012).

In the Safien valley, a tense relationship exists between the famers who have consciously chosen to apply traditionally acquired, agricultural strategies (often associated with extensive agricultural practices, for example when precipices that are too steep for machinery are scythed per hand), and farmers who operate as intensively as possible by using heavy machinery and intense fertilization. The issue of linkages between an apparent loss in biodiversity and particular agricultural strategies was brought up frequently in the interviews. The question of how high the subsidies for extensive, ecologically sustainable agriculture should be is politically and emotionally charged. These tensions manifest themselves in latent or open conflicts, such as those pertaining to land rights issues. With regard to the winners and losers in this new social-ecological development, a farmer from Safien Platz claims:

The problem is that the agricultural subsidy payments for mountain farms are paid mainly for the farmland 
and for the number of cattle owned. For the intensity and the amount of work, which is especially high on steep slopes, there is almost no compensation. Smallscale farmers are disadvantaged by this type of policy, while large farmers profit from it. This development also means that larger farms are able to buy up all the areas. As a result, fewer farms are able to survive economically next to each other and we are affected by the problem of depopulation. The loss of our small-scale farmland also leads to a loss of our cultural landscape, which is characterized by high biodiversity... I would say that in the valley there exists a strained relationship between farmers who try to expand their farmland and manage it as intensely as possible, without any regard to losses of biodiversity, and those who care about preserving this unique place (Interview with a farmer in Tenna, April 2012. Quote translated from German to English).

It becomes clear that the frames of reference that fundamentally structure the ways in which environmental change is experienced, how people understand the information they receive, and what actions and behavioral patterns result from it is the result of social negotiations and conflicts, which are imbued with aspects of power, authority, and legitimacy (Long and Long 1992; Sillitoe 1998; Pottier 2003; El Berr 2007). The data from the Safien valley show that it would be wrong to portray local environmental knowledge as necessarily promoting a heightened environmental awareness. Local environmental knowledge does not, by its mere existence, prevent an excessive consumption of natural resources. However, it would be just as wrong to argue the obverse.

\subsection{Local Perceptions of the Global Climate Change Discourse}

The local perception of global climate change discourse, and the actions that result from it, depend on various factors. The most interesting perceptions and actions relate to issues concerning vulnerability, resilience, and the ability of societies to adapt to unpredictable environmental changes:

Most people here do not believe in climate change and those that do, do not believe that humans are involved. When the topic of climate change is discussed at the regulars' table in the pub, it is dismissed as green propaganda. Along the lines "the theorists tell us practitioners how we have to do business." Maybe they are skeptical towards the issue, because the topic of climate could be connected with environmental regulations. Also I think that the awareness of the issue is very strongly related to the political orientation of each person. The BDP Party, ${ }^{7}$ which most farmers vote for here, is not exactly known for their environmental awareness. I and many other older farmers recognize lots of changes in the environment. For example, the tree line has changed. Today, young fir trees grow at almost 2,000 m, while 15 years ago, these trees only grew up to $200 \mathrm{~m}$ below that. Also, the weather has become more extreme. A few years ago the storm Lothar destroyed huge forest areas. Many trees in the valley simply folded over like matchsticks... (Interview with a carpenter from Tenna, January 2012. Quote translated from German to English).

Whether or not particular interpretations and actions related to climate change prevail depends on several factors and questions:

Does the respective person adhere to a value system that is open to "new" environmental discourses, sustainability issues, and the associated discussion of necessary changes within the economic system, or does he or she adhere to a value system in which topics such as climate change, environmental protection, and the relevant political agendas are avoided? The types of media (tabloids, radio, and so on) that are consumed also play an important role, and whether the result is a form of saturation or awareness towards the issue.

Another important question is what kinds of social pressures and informal rules exist to suppress or to allow for the recognition of new environmental ideas and concepts. Whether or not individuals who live in small-scale communities express critical viewpoints on environmental issues depends on how much the person is integrated within the community, the extent of social control, and the nature of power relations within the community, including gender-based inequalities. Statements that question the current economic system or environmental views and values are less likely to be articulated out of fear of causing social conflicts or due to an existing imbalance of power and codependent relationships.

Whether the person has inherited a piece of local environmental knowledge (field names, weather patterns, and so on) and how this knowledge is passed on and documented is another important factor. Usually, older people whose families have worked on a particular plot of land for several generations have a highly differentiated perception of nature and they tend to approach environmental changes in a more sensitive manner. It is especially these people

\footnotetext{
7 BDP (short name for Conservative Democratic Party Graubünden) is a conservative and right wing political party in the Canton Graubünden Switzerland.
} 
who often see a causal relation between extreme weather events and global warming.

\subsection{Applications of Local Environmental Knowledge that Lead to Increased Vulnerability or Resilience}

Climate change and its impact raise questions about a renewed sustainable behavior towards sensitive natural environments, and promote rapid change in the management of natural hazards (Wagner 2010). The research presented here responds to the question of what is meant by sustainability. It supports Charles Redman's comprehensive view that it is "bringing together a variety of perspectives-on society and the environment, how we make decisions and how we can go about it—in a way that will lead to a better, all-around world. Sustainability can be a form of applied anthropology and vice versa. Both domains are committed to rolling up their sleeves and getting involved; both are committed to making a difference and putting the person in the center" (Redman 2011, p. 12).

It has been proposed that professionals involved in disaster management often respond with the usual formal, scientifically developed and institutionally certified solutions to the global discourse on climate change, while often failing to reflect local reference frameworks and the basic associated changes in the interpretations of nature and society. The question is whether or not traditional environmental knowledge contributes to more flexible responses to changes in the natural environment caused by climate change and what happens when traditional environmental knowledge is lost.

During our research, it became obvious that many farmers, due to their continuous economic dependence on specific ecosystems, have fostered a sustainable use of natural resources that has been in place for centuries. Many of them have highly differentiated insights about their natural environment, including weather conditions and patterns of natural hazards and disasters. Still today this local knowledge is the basis for social and cultural, formal and informal norms and rules that often regulate the use of natural resources in a sustainable manner. According to Berkes, Colding, and Folke, this local knowledge can be viewed as a "library of information" that allows local actors to flexibly respond to future environmental changes, which contributes to the avoidance of vulnerability and the strengthening of resilience to catastrophic events (Berkes et al. 2000; Reichel et al. 2012):

The way in which we farm is still dominated by many of the traditional rules. There has to be some truth in them if things that we learned from our parents and grandparents are still valid today. Of course, we now live in a completely different era and we can work much more effectively; the past should not be romanticized. But I think our community is very good in combining these two issues on the one hand to sustain our cultural landscape through traditional knowledge and on the other hand to support our economic independence (Interview with the mayor and a farmer in Tenna, February 2012. Quote translated from German to English).

Following the concept of resilience, local environmental knowledge is a category that describes how societies and their various stakeholders understand uncertainties, disturbances, and surprises as triggers of a recursive learning process. Occurring irregularities are not considered insurmountable or as a life-threatening attack, but rather as the beginning of a transformation process in which people change their relationships with the natural resources according to a long-term and sustainable approach (Gallopin 2006; Berkes et al. 2008; Birkmann 2008; Bohle 2008; Voss 2008; ANiK 2013). By "learning to live with systems rather than control them" (Walker et al. 2002, p. 1), a resilient system provides the chance to take advantage of changes in a way that makes innovation and development possible. This leads us to the conclusion that if a social and/or ecological system loses resilience, peoples' and the environment's vulnerability to potentially adverse changes increases, which otherwise could have been avoided (Folke et al. 2002).

Our research has shown that in the complex relationship between culture, society, and nature, different dimensions of vulnerability may exist side by side. One example is the blind trust in or distrust of technical protection systems against natural hazards. If the probability of a catastrophic event, and the level of vulnerability, is drastically reduced through technological civil-engineering measures for avalanche control, simultaneously, avalanches that had occurred regularly are no longer a part of the dominant perception. As a result, the awareness of the threat of avalanches, which was commonplace in the recent past, is slowly replaced by a sense of complacency. Since technological civil-engineering measures for avalanche control can also encounter deficiencies during extreme events, this development leads to a certain increase of vulnerability for the local population in the long-term. This is especially relevant if the occurrence of extreme events is likely to increase, as may be the case in conditions of climate change. Therefore natural hazards, such as avalanches, pose a considerably smaller mental and practical challenge in places where they occur frequently and are expected to do so, as compared to places where they rarely occur, but are more likely to be extreme (Welzer 2009).

Professional stakeholders in risk and hazard management are becoming increasingly aware of the progressive 
potential of the resilience concept, instead of simply trying to keep social-ecological systems as stable as possible and in balance. With the exploration of local knowledge and its integration into risk and hazard management, one can develop an approach that directs attention to the acquisition of local skills and knowledge that help the local population adapt to and cope with future environmental changes.

\section{Conclusion}

The aim of this research was to better understand how the global phenomenon of climate change affects social realities at the local level and how to learn from people who still interact with nature and are in "communication" with the environment in a sustainable way.

Climate change and related natural hazards expand the realm of experience for the interdependency between society and nature within the most diverse global locations. The causal lines between everyday life, culture, and science are no longer clear, but become blurred and multilayered (ANiK 2013). Based on this background, the present data indicates that global phenomena such as climate change will only become tangible and meaningful when people interpret them on the basis of dominant cultural concepts. According to Roncoli et al. (2009), there are four aspects that play an essential role in the question of how a global phenomenon like climate change will become meaningful on the local level. The first important aspect is perception: How people perceive climate change through cultural lenses. The second aspect is knowledge: How people comprehend what they see based on their mental models and their social locations. The third is valuation: How they give value to what they know in terms of shared meanings. Finally: How they respond, individually and collectively, on the basis of these meanings and values. Cultural interpretations of climate change and hazards are constructed differently across various societies. They result from the given social, cultural, and geographical contexts and the individual experiences connected to them. Therefore, the strategies to prevent, respond to, and remember natural hazards also differ depending on the given social and cultural context.

This research aims at establishing systematic mapping of sustainable environmental knowledge, which we identify as a significant part of "cultural memory." We have shown how visualized forms of local knowledge may contribute to an improved adaptation to climate change. Long-term cultural memory is important for renewed sustainable environmental management. The cartographic approachwhich is relatively new within the fields of social and cultural anthropology - allows recommendations for action to become more easily communicable, encourages interdisciplinary cooperation, and allows the local population to actively participate in the process of risk management. Participatory mapping may allow for more efficient, sustainable, and pluralistic forms of risk and hazard management, and a greater acceptance by the local population. From our point of view, the ideological power play and the role of natural disaster management need further discussion. But rather than simply stating that there are two worldviews in tandem, we try to show that the multimedia map presented above can be one-way of allowing different worldviews to communicate, to the benefit of the local population and professionals in risk management, such as scientific advisors and political actors.

However, the potential of participatory methods is rarely used, and the integration of local knowledge, to broaden an adaptive governance approach in the face of the specific challenges associated with climate change and natural hazards in alpine areas, is just beginning. The strongest demand raised for an applied and widely understandable science is formulated by nature itself through climate change and its impacts. With this research, we attempt to listen and begin to offer some modest steps towards potential solutions.

Acknowledgments Special thanks go out to all of the people who gave us confidence and support during our research and offered us a glimpse into their world. We would especially like to thank: Christian Messmer, Tamara Bühler, Erika and Erwin Bandli, Thomas Buchli, Paul Gartmann, and Hansjürg Gredig. Without them our research would not have been possible. We also would like to thank the editors of this Special Issue, Dr. Alexander Fekete and Dr. Gabriele Hufschmidt, who helped to improve this article by engaging in very constructive and helpful discussion. The research in Switzerland, with the title "Visualization and Mapping of Alpine Local Knowledge in Times of Climate Change," was funded by the German Federal Ministry of Education and Research (BMBF-Bundesministerium für Bildung und Forschung) between 2011 and 2014, as part of the interdisciplinary joint research project "Alpine Hazards in Times of Climate Change. Patterns of Interpretation and Strategies of Action from the 18th to the 21st Century." The authors are thankful to their colleagues in this joint research project: Prof. Manfred JakubowskiTiesen (Georg-August University Göttingen, Seminar on Medieval and Modern History); Dr. Sylvia Kruse and Prof. Irmi Seidel (Federal Institute for Forest, Snow and Landscape Research WSL, Switzerland); Prof. Martin Voss (Freie Universität Berlin, Institute of Social and Cultural Anthropology, Disaster Research Area); Dr. Klaus Wagner (Munich University of Technology, Chair for Forest and Environmental Politics).

Open Access This article is distributed under the terms of the Creative Commons Attribution License which permits any use, distribution, and reproduction in any medium, provided the original author(s) and the source are credited.

\section{References}

Agrawal, A. 1995. Dismantling the divide between indigenous and scientific knowledge. Development and Change 26(3): 413-439. 
ANiK (Alpine Naturgefahren im Klimawandel). 2013. Alpine hazards in times of climate change. Patterns of interpretation and strategies of action from the 18th to the 21st century. http:// alpine-naturgefahren.de. Accessed 13 Jan 2014.

Appadurai, A. 1986. The social life of things: Commodities in cultural perspective. Cambridge: Cambridge University Press.

Assmann, A. 2011. Cultural memory and western civilization. Cambridge: Cambridge University Press.

BAFU (Bundesamt für Umwelt/Swiss Federal Office for the Environment). 1999. Leben mit dem Lawinenrisiko. Bern. http:// www.bafu.admin.ch/publikationen/publikation/00782/index.html? lang=de (in German). Accessed 16 Oct 2013.

BAFU (Bundesamt für Umwelt/Swiss Federal Office for the Environment). 2013. Klimawandel: Folgen für die Schweiz. http:// www.bafu.admin.ch/klima/00469/00810/index.html?lang=de (in German).

Banks, M. 2001. Visual methods in social research. London: Sage Publications.

Berkes, F., J. Colding, and C. Folke. 2000. Rediscovery of traditional ecological knowledge as adaptive management. Ecological Applications 10(5): 1251-1262.

Berkes, F., J. Colding, and C. Folke (eds.). 2008. Navigating socialecological systems: Building resilience for complexity and change. Cambridge: Cambridge University Press.

Birkmann, J. 2008. Global Environmental change, natural hazards, vulnerability, and catastrophe resilience: The need to expand perspectives in regional planning (Globaler Umweltwandel, Naturgefahren, Vulnerabilität und Katastrophenresilienz: Notwendigkeit der Perspektivenerweiterung in der Raumplanung). Raumforschung und Raumordnung 66(1): 5-22 (in German).

Blumberg, H. 1986. The legibility of the world (Die Lesbarkeit der Welt). Frankfurt am Main: Suhrkamp Verlag (in German).

Bohle, H.-G. 2008. Live with the Risk-Resilience as a new paradigm for risk environments of tomorrow (Leben mit dem RisikoResilience als neues Paradigma für die Risikowelten von morgen). In Natural hazards and social disasters (Naturrisiken und Sozialkatastrophen), ed. C. Felgentreff, and C. Glade, 435-441. Berlin: Springer Verlag (in German).

Bätzing, W. 2005. The Alps: History and future of a European cultural landscape (Die Alpen: Geschichte und Zukunft einer europäischen Kulturlandschaft), 3rd ed. Munich: Beck Verlag (in German)

Chambers, R. 2006. Participatory mapping and geographic information systems: Whose map? Who is empowered and who disempowered? Who gains and who loses? Electronic Journal of Information Systems in Developing Countries 25(2): 1-11.

Crate, S. 2009. Anthropology and climate change: From encounters to actions. Walnut Creek: Left Coast Press.

DWD (Deutscher Wetterdienst - Bundesministerium für Verkehr und digitale Infrastruktur/German Weatherforcast - Federal Ministry of Transport and Digital Infrastructure). 2014. Starkregen (Starkniederschlag). http://www.deutscher-wetterdienst.de/lexikon/index. htm?ID=S\&DAT=Starkregen (in German). Accessed 20 Jan 2014.

Dietz, K. 2006. Vulnerability and adaptation to climate change from a social-ecological perspective. Current trends and challenges in international climate and development politics (Vulnerabilität und Anpassung gegenüber Klimawandel aus sozial-ökologischer Perspektive. Aktuelle Tendenzen und Herausforderungen in der internationalen Klima- und Entwicklungspolitik). Berlin: Diskussionspapier 01/06 des Projektes: Global Governance und Klimawandel (in German).

Eichborn, S. 2001. Local knowledge as a chance in development cooperation: Should everything stay as it is? (Lokales Wissen als Chance in der Entwicklungszusammenarbeit (EZ): Soll alles bleiben wie bisher?), vol. 77. Berlin: Das Arabische Buch (in German).
El Berr, S. 2007. From ecosaint to environmental destroyer and back: Indigenous knowledge in development cooperation (Vom Ökoheiligen zum Umweltzerstörer und zurück: Indigenes Wissen in der Entwicklungszusammenarbeit). In Of honey and university: Thirteen socially critical interventions (Von Honig und Hochschulen: Dreizehn gesellschaftskritische Interventionen), ed. G. Jilek, S. Kalmring, and S. Müller, 94-122. Berlin: Zehntes DoktorandInnenseminar der Rosa Luxemburg, Stiftung (in German).

Folke, C., S. Carpenter, T. Elmqvist, L. Gunderson, C. S. Holling, B. Walker, J. Bengtsson, and F. Berkes, et al. 2002. Resilience and sustainable development: Building adaptive capacity in a world of transformations. ICSU Series on Science for Sustainable Development No. 3. International Council for Scientific Unions, Paris or the Swedish Environmental Advisory Council, Ministry of the Environment, Stockholm.

Foucault, M. 1971. The order of discourse ( $L^{\prime}$ ordre du discours). Paris: Galimart (in French).

Frömming, U.U. 2006. Natural disasters: Cultural interpretation and processing (Naturkatastrophen: Kulturelle Deutung und Verarbeitung). Frankfurt am Main: Campus (in German).

Frömming, U.U., and C. Reichel. 2011. Vulnerable coastal regions: Indigenous people under climate change in Indonesia. In Religion in environmental and climate change: Suffering, values, lifestyles, ed. D. Gerten, and S. Bergmann, 215-235. London: Continuum International.

FSO (Swiss Federal Statistical Office). 2014. Swiss Federal Statistical Office. http://www.bfs.admin.ch/bfs/portal/en/index.html. Accessed 5 Sept 2013.

Gallopin, G.C. 2006. Linkages between vulnerability, resilience, and adaptive capacity. Global Environmental Change 16(3): 293-303.

Gerten, D., and S. Bergmann. 2012. Facing the human faces of climate change. In Religion in environmental and climate change: Suffering, values, lifestyles, ed. D. Gerten, and S. Bergmann, 3-15. London: Continuum International.

Heesen, J., D. F. Lorenz, M. Nagenborg, B. Wenzel, and M. Voss. 2014. Blind spots on Achilles' heel: The limitations of vulnerability and resilience mapping in research. International Journal of Disaster Risk Science 5(1). doi:10.1007/s13753-014-0014-5.

IFAD (International Fund for Agricultural Development). 2009a. Good practices in participatory mapping. Rome. http://www. ifad.org/pub/map/PM_web.pdf. Accessed 21 Aug 2013.

IFAD (International Fund for Agricultural Development). 2009b. The IFAD adaptive approach to participatory mapping. Rome. http:// www.ifad.org/pub/map/pm_ii.pdf. Accessed 15 Aug 2013.

Ingold, T. 2000. The perception of the environment: Essays on livelihood, dwelling and skill. London: Routledge.

IPCC (Intergovernmental Panel on Climate Change). 2007. Climate change 2007: Synthesis report. Geneva. http://www.ipcc.ch/pdf/ assessment-report/ar4/syr/ar4_syr.pdf. Accessed 20 July 2013.

Kruse, S., and J. Wesely. 2013. Workshop report: Adaptive management of natural hazards. appropriate measures for adapting organizations in times of climate change (Workshopbericht: Adaptives Naturgefahrenmanagement. Passende Maßnahmen für angepasste Organisationen in Zeiten des Klimawandels). Chur. http://www.wsl.ch/fe/wisoz/projekte/anik/ANiK_Workshopber icht_Adaptives_Naturgefahrenmanagement_2013_final.pdf (in German). Accessed 2 Jan 2014.

Long, N., and A. Long. 1992. In battlefields of knowledge: The interlocking of theory and practice in social research and development. London: Routledge.

Luig, U. 2012. Negotiating disasters: Politics, representation, meanings. Frankfurt am Main: Peter Lang Verlag.

Massey, D. 2000. Travelling thoughts. In Without guaranties: In honour of Steward Hall, ed. P. Gilroy, L. Grossberg, and A. MacRobbie. New York: Verso. 
McDougall, D. 1995. Beyond observational cinema. In Principals of visual anthropology, ed. P. Hockings, 115-133. Berlin: The Hague Mouton de Gruyter.

MeteoSwiss (Swiss Federal Office of Meteorology and Climatology). 2013. Berichte und Links zur Klimaänderung. http://www. meteoschweiz.admin.ch/web/de/klima/klima_morgen/berichte_ links_klimaaenderung.html. Accessed 5 Dec 2013.

Municipal Government Safien. 2014. Gemeinde Safiental. http:// www.safiental.ch/Gemeinde/ (in German). Accessed 5 Feb 2014.

OcCC (Organe consultatif sur les changements climatiques). 2003. Extreme events and climate change. Bern. http://www.occc.ch/ reports/Extremereignisse03/Extrem03_Report.html. Accessed 8 Nov 2013.

OcCC (Organe consultatif sur les changements climatiques). 2007. Climate change and Switzerland 2050-Expected impacts on environment, society, and economy. Bern. http://proclimweb. scnat.ch/Products/ch2050/ch2050-report.html. Accessed 8 Nov 2013.

PLANAT (Nationale Plattform für Naturgefahren/National Platform for Natural Hazards). 2013. Disaster risk reduction (DRR) and climate change adaption (CCA) in international cooperation. A landscape of swiss expertise. Project D5. Bern. http://www. planat.ch/en/marketing-materials-detail-view/datum/2013/06/18/ disaster-risk-reduction-drr-and-climate-change-adaption-cca-ininternational-cooperation/. Accessed 15 Feb 2014.

Pottier, J. 2003. Negotiating local knowledge: An introduction. In Negotiating local knowledge: Power and identity in development, ed. J. Pottier, A. Bicker, and P. Silitoe, 1-29. London: Pluto Press.

Rebetez, M. 2006. Switzerland warms up. The greenhouse effect and climate change (La Suisse se réchauffe. Effet de serre et changement climatique). Le savoir Suisse. Lausanne: Presses polytechniques et universitaires romandes (in French).

Redman, C. 2011. Anthropology as key to sustainability science: An interview with Charles Redman. Anthropology News 52(4): 12.

Reichel, C., U.U. Frömming, and M. Glaser. 2009. Conflicts between stakeholder groups affecting the ecology and economy of the Segara Anakan region. Regional Environmental Change 9(4): 335-343.

Reichel, C., S. Martens, and A. Harms. 2012. Conflicting frames of reference, environmental changes in coastal Indonesia. In Environmental uncertainty and local knowledge, southeast Asia as a laboratory of global ecological change, ed. A.K. Hornidge, and C. Antweiler, 93-119. Bielefeld: Transcript Verlag.

Robertson, R. 1995. Glocalization: "Time-Space and HomogeneityHeterogeneity." In Global modernities, ed. M. Featherstone, 25-44. London: Sage Publications.

Roncoli, C., T. Crane, and B. Orlove. 2009. Fielding climate change in cultural anthropology. In Anthropology and climate change:
From encounters to actions, ed. S. Crate, and M. Nuttall, 87-116. Walnut Creek: Left Coast Press.

Schultze, U. 1998. Local knowledge and development cooperationAn introduction (Lokales Wissen und Entwicklungszusammenarbeit-Eine Einführung). In Local Knowledge for a sustainable development: A Praxis guide (Lokales Wissen für nachhaltige Entwicklung: Ein Praxisführer), ed. S. Pasquale, P. Schröder, and U. Schultze, 1-56. Saarbrücken: Verlag für Entwicklungspolitik (in German).

Scoones, I., and J. Thompson. 1994. Knowledge, power and agriculture-Towards a theoretical understanding. In Beyond farmer first: Rural people's knowledge, agricultural research and extension practice, ed. I. Scoones, and J. Thompson, 16-32. London: IT Publications.

Sillitoe, P. 1998. The development of indigenous knowledge: A new applied anthropology. Current Anthropology 39(2): 223-252.

Steinmann, B., E. Bardill, and M. Hunger-Fry. 2008. Safien ValleyRuinaulta, from the Safier Mountain to the Rhin Gorge (Safiental-Ruinaulta, Vom Safierberg zur Rheinschlucht). Chur: Terra Grischuna Verlag (in German).

Sturm, G. 2000. Paths to space: Methodological approaches to a basic concept in the space-related sciences (Wege zum Raum: Methodologische Annäherung an ein Basiskonzept raumbezogener Wissenschaften). Habilitation, Universität Dortmund. Oplanden: Leske + Budrich (in German).

Tsing, A. 2005. Friction: An ethnography of global connection. Princeton: Princeton University Press.

Voss, M. 2008. The vulnerable can't speak: An integrative vulnerability approach to disaster and climate change research. Behemoth: A Journal on Civilisation 1(3): 39-56.

Voss, M. (ed.). 2010. The climate change -Social science perspectives (Der Klimawandel_Sozialwissenschaftliche Perspektiven). Wiesbaden: VS Verlag für Sozialwissenschaften (in German).

Wagner, K. 2010. Climate change as a trigger of rapid change in natural hazard management (Der Klimawandel als Auslöser eines rapiden Wandels im Naturgefahrenmanagement). In The climate changesocial science perspectives (Der Klimawandel-Sozialwissenschaftliche Perspektiven), ed. M. Voss, 363-376. Wiesbaden: VS Verlag für Sozialwissenschaften (in German).

Walker, B., S. Carpenter, J. Anderies, N. Abel, G.S. Cumming, M. Janssen, L. Lebel, J. Norberg, et al. 2002. Resilience management in social-ecological systems: A working hypothesis for a participatory approach. Ecology and Society 6(1): Article 14.

Welzer, H. 2009. Climate wars: What we are killing for in the 21st century (Klimakriege. Wofür im 21, Jahrhundert getötet wird). Frankfurt am Main: Fischer Verlag (in German).

Wood, D. 2012. The anthropology of cartography. In Mapping cultures: Place, practice, performance, ed. L. Roberts, 280-303. New York: Palgrave Macmillan. 